\title{
'VOLSTREKT REALISTISCHE SITUATIES IN COMPUTERGAMES? DIE HEBBEN WE THUIS AL'
} (REVIEW)

Steven L. Kent, The ultimate history of videogames. From Pong to Pokémon and beyond.... The story behind the craze that touched our lives and changed the world. Roseville, California (Prima Publishing) 200 , 608 p., geïll., Is в N 0761536434

Rusel DeMaria \& Johnny L. Wilson, High Score! The illustrated history of electronic games, 2nd edition. Emeryville, California (McGraw-Hill/Osborne) 2004, 392 p., geïll., І s в N 0 O 2231726

Steven Poole, Trigger Happy. The inner life of videogames. London (Fourth Estate Limited) 2000, 262 p., geïll., IS B N I 84II5 I2I I

James Newman, Videogames. London (Routledge) 2004, I98 p., IS B N 04 II 28I92 X

Waar ooit boeken over computerspellen een zeldzaamheid waren, worden ze nu in een steeds hoger tempo geproduceerd. De snel groeiende omvang van de spellenindustrie en de spelersgemeenschap rechtvaardigt dit. Maar van een gevestigd academisch veld kunnen we nog niet spreken. Dit vindt niet alleen zijn weerslag in de catalogisering van deze werken in boekhandels en bibliotheken maar ook in het (gesuggereerde) academische gehalte van hun inhoud. In deze recensie worden vier recente boeken over het computerspel nader bekeken. Twee boeken zijn historisch en twee zijn algemener van aard, maar vooral de verschillen tussen al deze boeken zijn opvallend.

The Ultimate History of Videogames, From Pong to Pokémon and beyond..., The story behind the craze that touched our lives and changed the world heeft de langste titel van de vier boeken. Verbazendwekkend is echter dat een aantal cruciale woorden in deze titel ontbreekt. The Ultimate History of Videogame Companies, From the East to the West Coast and a little bit beyond... was een veel betere titel 
geweest. Ondanks vele korte beschrijvingen van klassieke spellen, is het boek voornamelijk een geschiedenis van de industrie, en dan met name het verhaal van het Amerikaanse bedrijf Atari, en de Amerikaanse afdelingen van Nintendo en Sega. De hoofdrollen worden vertolkt door de 'chief executive officers', 'presidents' en 'vice presidents of engineering' die vaak in flatterende omschrijvingen worden geïntroduceerd. Een goed voorbeeld is Jim Whims (de 'senior vice president of marketing' van Sony Computer Entertainment of America) die wordt omschreven als 'Tall, comfortable around strangers, and athletically built, Whims had the look of a leader' (p. 505). De bijna tragische heroïek van vooral de Atari medewerkers wordt regelmatig afgezet tegen de kille kapitalistische mentaliteit van een aantal zakenlieden aan de Amerikaanse oostkust en de conservatieve Japanse bedrijfsleiders. En dat is jammer, want ondanks dat het boek in het begin nog een beetje de charme heeft van een spannend jongensboek, blijft het niet alle zeshonderd pagina's boeien. Erger nog, de spellen waar het boek over zou moeten gaan verdrinken in de vele beschrijvingen van bedrijfsplannen, transcripties van rechtszaken en de cv's van de managers. De belofte op de achterflap dat het boek 'Entertaining, addictive, and as mesmerizing as the games it chronicles' is, wordt dan ook absoluut niet waargemaakt.

Dit betekent echter niet dat het boek geen waarde heeft. Het verschaft een belangrijk inzicht in de praktijk van de computerspellenindustrie. Een aantal rechtszaken dat aan bod komt is zeker van historisch belang, en vooral de beschrijvingen van de verhoren door de Amerikaanse Senaat over het verband tussen geweld en computerspellen zijn de moeite waard. Voor de lezer die geïnteresseerd is in de prijzen van spellen en spelcomputers door de jaren heen en de strategie om deze aan de man te brengen, bevat The Ultimate History een schat aan informatie. Voor degene die geïnteresseerd is in de computerspellen zelf is het interessant om te zien welke rol deze spellen speelden in de ontwikkeling van de industrie. Daarnaast bevat het boek nog een aantal aardige anekdotes die het wellicht nog goed doen in de kroeg. Voorbeelden zijn het tekort aan kleingeld in Japan na de introductie van SPACE InVADERS, en de blunder die Atari maakte toen het, na de contracten al te hebben ondertekend, afzag van het op de markt brengen van de spelcomputer van nieuwkomer Nintendo (een fout die ze overigens nog eens dunnetjes overdeden toen Sega met hetzelfde voorstel kwam, hetgeen het doodvonnis was van het eens zo grote Atari).

Van belang is ook dat de Nederlandse term 'computerspellen' correspondeert met drie Engelse termen: computer games, videogames en arcade games. In het Engels worden met de eerste term meestal alleen spellen op de PC aangeduid, videogames worden gespeeld op spelcomputers (aangesloten op de TV en zonder toetsenborden) en arcade games zijn de kasten die zij aan zij met flipperkasten en gokautomaten in speelhallen zijn te vinden. The Ultimate History is vooral een geschiedenis van de laatste twee. Computer games worden hier en daar zijdelings genoemd en slechts in één paragraaf wordt er uitgebreider op in gegaan (pp. 455-460). Het resultaat is dat een groot aantal klassiekers op dit 
gebied geen aandacht krijgt. De meest opvallende afwezige is het tekstspel ADVENTURE dat in I975 aan de bakermat stond van een heel genre van interactieve fictie. Het spel wordt alleen terloops genoemd als bron van de grafische Atari adaptatie met dezelfde naam. En dat spel verdient zijn plaats in The Ultimate History voornamelijk omdat het de eerste 'easter egg' bevat, zonder dat goed uitgelegd wordt wat nu het precieze belang van een 'easter egg' is.'

Eén van de erfgenamen van ADVENTURE is het beruchte PC-spel LEISURE SU IT LARRY (I987) dat eind jaren tachtig een ware hype veroorzaakte en veelal in kantoren werd gespeeld. De volwassen inhoud van dit spel (de 'queeste' betrof ervoor te zorgen dat de antiheld Larry binnen 24 uur de liefde moest bedrijven) en de grote hoeveelheid illegale kopieën hebben een grote impact gehad op de bekendheid en verspreidingswijze van spellen. De geruchten dat de illegale versie van LEISURE SUIT LARRY een virus bevatte dat geactiveerd werd zodra de hoogst mogelijke score van 222 punten werd behaald, droeg eerder bij aan de spanning en de hype dan dat het kantoorpersoneel afschrok. LEISURE SUIT LARRY zou om deze redenen niet hebben misstaan in de institutionele geschiedenis van Kent.

Wat dat betreft is High Score! The illustrated history of electronic games veel completer. Het behandelt zowel videogames, computer games als arcade games. In de index van High Score! staan ongeveer tweehonderd spellen, dat is op het eerste gezicht minder dan de ruim vierhonderd spellen in de index van The Ultimate History. Echter, waar Kent die vierhonderd spellen vaak zijdelings noemt, behandelen DeMaria en Wilson de spellen redelijk uitgebreid, met niet alleen informatie over wie het wanneer ontworpen heeft, maar ook over hoe het spel gespeeld wordt en welke technische (on)mogelijkheden een rol speelden bij het ontwerpproces. Bij bijna elk spel zijn één of meerdere screenshots opgenomen, en er zijn minstens evenveel reproducties van de bijbehorende verpakkingen, brochures en handleidingen. Vooral de ontwerpschetsen en storyboards die hier en daar te vinden zijn, zijn interessant.

Behalve deze tweehonderd spellen wordt er nog een behoorlijk aantal spellen genoemd dat niet in de index staat. Vaak zijn er ook nog screenshots of verpakkingen van deze spellen afgebeeld. Vooral spellen van na 2000 komen er op deze manier wat bekaaid vanaf, maar een omissie is dit nauwelijks te noemen aangezien het boek vooral de jaren zeventig, tachtig en negentig behandelt.

Net zoals The Ultimate History is de opzet van High Score! chronologisch. Beide boeken beginnen met een hommage aan de flipperkast en de novelty machine als voorlopers van arcade spellen. Beide noemen SPACE WAR (I96II962) als belangrijkste inspiratiebron voor Nolan Bushnell om in I972 Atari op te richten. PonG, het eerste spel dat Atari in I972 op de markt bracht, was wellicht niet het eerste computerspel maar wel het eerste spel dat een commercieel succes was. Waar The Ultimate History vooral de grote Amerikaanse marktpartijen volgt, gaat High Score! veel meer uit van de klassieke spellen en komen veel 
kleinere bedrijven aan bod. Echter, High Score! is eerder een koffietafelboek dan een gedegen geschiedenis. De teksten zijn redelijk fragmentarisch en soms wat jolig geschreven. De chronologische lijn wordt regelmatig onderbroken door thematische uitstapjes, waardoor het mogelijk wordt dat een spel uit I998 terug te vinden is in het hoofdstuk over de jaren tachtig. Dit zorgt ervoor dat het boek niet gemakkelijk van voor tot achter te lezen is, maar de schat aan visuele informatie maakt het wel tot een naslagwerk dat vooral een goed inzicht geeft in de (ontwikkeling van de) visuele stijl en speelstijl van het computerspel. Handig om op je bureau te hebben liggen bij het lezen van de andere boeken in deze recensie.

De tweede editie van High Score! is uitgebreid met twee appendices over Britse en Japanse spellen. Niet dat spellen uit deze landen in de rest van het boek geen aandacht krijgen, maar deze is niet zo groot als de aandacht voor Amerikaanse spellen. Helaas richten deze twee uitbreidingen zich voornamelijk op de bedrijven en minder op de spellen zelf. De hoeveelheid thematische uitstapjes zijn in deze appendices een stuk minder waardoor het geen evenwichtige toevoegingen zijn aan de rest van het boek.

Waar het beide boeken aan ontbreekt is een gedegen wetenschappelijke benadering van hun onderwerp. Geen van de boeken doet een poging een definitie te geven van of zelfs maar uit te leggen wat de belangrijkste eigenschappen van een computerspel zijn. Beide boeken bevatten veel jargon en zijn daardoor niet heel toegankelijk voor mensen die niets van computerspellen weten. Zonder enige ervaring met computerspellen, of kennis van klassieke titels is High Score! vooral een chaotische brei van korte teksten en afbeeldingen. De auteurs zijn veteranen van de spellenjournalistiek (Wilson) en de spellenindustrie (DeMaria), en het lijkt erop dat zij vooral geschreven hebben voor fanatieke en geïnteresseerde spelers, journalisten en spelontwerpers. Jammer is dat het boek daardoor een aantal kansen laat liggen. Bijvoorbeeld, begin jaren negentig hanteerden aartsrivalen Nintendo en Sega duidelijk gedifferentieerde visuele stijlen. Nergens in High Score! is er een plek waar deze vergelijking specifiek wordt gemaakt.

Kent is eveneens een journalist die (zoals was te verwachten) onder andere de economische kant van de spellenindustrie heeft verslagen voor diverse Amerikaanse kranten en tijdschriften. Zijn boek leunt slechts op een handvol boeken en artikelen en vooral op een groot aantal interviews met de captains of industry. Het ontsluit een schat aan informatie over de verkoopcijfers, rechtszaken en verhoren die van belang zijn voor de ontwikkeling van de computerspellenindustrie, maar het geeft vooral een goede eerste indruk. Een onderzoeker die geïnteresseerd is in dit materiaal doet er beter aan zich meteen te wenden tot de bronnen waarop Kent zich baseert.

Een meer wetenschappelijke benadering is wel terug te vinden in Trigger Happy en Videogames. Hoewel geschiedenis in deze boeken een rol speelt zijn beide 
boeken in de eerste plaats studies van het computerspel als cultureel en maatschappelijk object.

Steven Poole benadert computerspellen in Trigger Happy, The inner life of videogames als een kunstvorm. Belangrijkste argument hiervoor is dat de reactie van spelers op een goed ontworpen spel voor een belangrijk deel een esthetische reactie is, vergelijkbaar met de receptie van films of schilderijen. De reden hiervoor is dat computerspellen het product zijn van een creatief proces, waarin het talent en de vaardigheid van de betrokken grafische ontwerpers, muzikanten, geluidsontwerpers en schrijvers een doorslaggevende rol speelt. Poole's belangrijkste doel is erachter te komen waarom sommige spellen op basis hiervan beter worden ontvangen dan andere. (p. 25) Hiertoe analyseert hij verschillende onderdelen van het computerspel in hoofdstukken die gaan over het filmische karakter, het verhaal, de grafische aspecten, en de karakters. De belangrijkste boodschap die in deze hoofdstukken naar voren komt blijft toch dat het computerspel een onafhankelijke kunstvorm is, met meer verschillen dan overeenkomsten met bestaande kunstvormen zoals film, literatuur en de schilderkunst.

Een belangrijk, terugkerend thema in Trigger Happy is realisme en simulatie in computerspellen. Simulatie is een onderdeel van elk computerspel, maar Poole stelt terecht dat wat gesimuleerd wordt vaak niet in de werkelijkheid bestaat. In een spitsvondige passage over het realisme van de laserstraal in zogenaamde space shoot-'em-ups zet hij realisme en speelbaarheid tegen elkaar af: een echte laserstraal is onzichtbaar en raakt zijn doel vrijwel onmiddellijk, geen ingrediënten die een spel leuk maken. Realisme in computerspellen is in zijn ogen altijd problematisch:

'Videogame's somewhat paradoxical fate is the ever more accurate modelling of things that don't, and couldn't, exist: a car which grips the road like Superglue, which bounces uncrumpled off roadside barriers; a massive spacecraft with the manoeuvrability of a humble bee; a human being who can survive, bones intact, a three-hundred-foot fall into water. We don't want absolutely real situations in videogames. We can get that at home.' (p. 64)

Dit leidt er zelfs toe dat Poole de toekomst van computerspellen niet per definitie zoekt in Virtual Reality (VR):

'Immersive VR will be fine for exploration games, driving games, 3D space shoot-'em-ups and so on. But what happens to the pleasurable unreality of human-body physics? How will such a system enable the player to somersault like Lara Croft, to climb sheer walls, to swim a hundred feet down in icy Artic rivers or to finish off a brutal martial arts combination of smacks and punches by floating six feet in the air and delivering a round-house kick to the head?' (p. 77) 
Deze benadering differentieert Trigger Happy van klassiekers op het gebied van interactieve fictie zoals J.H. Murrays Hamlet On The Holodeck (I997) en stelt S. Poole in staat ver door te dringen in het specifieke karakter van het computerspel. Eén hoofdstuk is zelfs gewijd aan de middelen die gebruikt worden om het computerspel te spelen, zoals toetsenborden, joysticks en joypads. Dit alles om (terecht) het belang van het actieve spelelement te benadrukken. De hieruit voortvloeiende, en soms radicale voorstellen voor de richting waarin het computerspel zich zou kunnen ontwikkelen zijn erg interessant waarbij Poole een goed oog houdt voor het verschil tussen simulatie en spel. Helaas blijft het wat dat betreft vaak bij speculaties.

De asymmetrie tussen filmische en grafische aspecten enerzijds en de narratieve aspecten anderzijds is wat dat betreft opvallend. Poole ziet geen werkelijke, interactieve fictie ontstaan op korte termijn, net zoals hij de interactieve film niet de meest logische stap vindt in de verdere ontwikkeling. Toch ziet hij wel allerlei 'filmachtige' ontwikkelingen die het eigene van het spel kunnen benadrukken. Dat laatste geldt niet voor de narratieve aspecten van het computerspel. De belangrijkste reden hiervoor is dat volgens Poole een goed verhaal vooral gebaseerd is op interessante interactie tussen karakters. De huidige generatie spelcomputers is niet toegerust met een toetsenbord en dat beperkt de mogelijkheden voor interactie tot slechts een paar handelingen, vaak een simpele keuze uit een aantal dialoogopties (p. I2I). De ontwikkelingen op het gebied van de grafische representatie en kunstmatige intelligentie krijgen dan ook veel meer aandacht van de industrie dan de ontwikkelingen op het gebied van interactie en dialoog. Dit zijn terechte constateringen maar hiermee gaat Poole helaas voorbij aan de PC waar de mogelijkheden uitgebreider zijn (hoewel zelden toegepast) en weigert hij verder te denken dan de huidige situatie, zoals hij dat wel doet in andere hoofdstukken. De belangrijkste reden hiervoor zal wel zijn dat we volgens Poole 'don't want to have to make crucial narrative decisions that might, in effect, spoil the story for us' (p. I23). Deze opvatting lijkt mij een persoonlijke opvatting van Poole zelf. Eén die niet rechtstreeks afgeleid kan worden van zijn opvatting over computerspellen in het algemeen. Er zijn echter nog tal van tussenvormen te bedenken die wel werken, die wellicht een verhaal kunnen vertellen zonder dat de speler de cruciale narratieve beslissingen hoeft te nemen terwijl het toch nog een spel kan blijven. Dat zoiets mogelijk moet zijn wordt onder andere aangetoond door een aantal spellen zoals B LADE RUNNER die succesvol een gecompliceerd verhaal wisten te vertellen ondanks deze technologische beperkingen (zie Newman 2004: pp. I04-I05). Desalniettemin blijft de (vermeende) tegenstelling tussen verhaal en spel een heet hangijzer in de academische discussie.

In een hoofdstuk over de semiotiek van het computerspel slaat Poole de plank enigszins mis. De semiotische analyses beperken zich grotendeels tot het identificeren van symbolen, iconen en indexen. De claim dat PAC-MAN ongebreideld consumentisme propageert, is een aardige exercitie in structuralisme 
maar lijkt nogal vergezocht en wordt niet of nauwelijks gefundeerd (pp. I89I90). Maar dat neemt niet weg dat Trigger Happy een vlot geschreven en goede introductie is in de wereld van het computerspel. De schrijfstijl houdt het midden tussen die van een journalistiek en van een wetenschappelijk werk. Dit reflecteert meteen de academisch/journalistieke achtergrond van de auteur zelf. Het boek was wel beter af geweest met een meer uitgebreide bibliografie en een betere bronverwijzing. Nu lijkt Poole zich voornamelijk te baseren op L'Univers des Jeux Vidéo van Alain en Frédéric le Diberder (I998).

James Newman's Videogames gaat net zoals de andere boeken in de eerste plaats over spelcomputerspellen. PC-spellen en arcade games komen wel uitgebreid aan bod maar spelen respectievelijk de tweede en derde viool (hoewel op de omslag een PC en geen spelcomputer is afgebeeld). Videogames is een grondige en gedegen introductie in de wereld van het computerspel. In tien hoofdstukken gaat Newman uitgebreid in op wat een computerspel nu precies is en waarom het bestudeerd zou moeten worden. Hij beschrijft de industrie en hoe deze zich de laatste jaren heeft ontwikkeld van kleine bedrijven naar grote productiestudio's met gespecialiseerde werknemers, hij ontleedt de spellen in verschillende onderdelen en heeft een duidelijk oog voor de sociale context. Zijn academische benaderingswijze zorgt ervoor dat bijvoorbeeld zijn hoofdstuk over de spellenindustrie, ondanks de korte lengte, een stuk zakelijker, leesbaarder en minstens zo informatief is als The Ultimate History in zijn geheel. Newman is de enige auteur met een puur academische achtergrond. Hij was de eerste persoon die in Groot-Brittannië promoveerde op computerspellen en publiceerde eerder op academische websites zoals Gamestudies.org. De uitgebreide bibliografie en goede bronverwijzing maken dan ook een solide indruk.

De relatief korte lengte van Videogames, de grote hoeveelheid stof die de revue passeert en het ontbreken van een duidelijke richtinggevende these (zoals Poole die wel heeft) zorgen er helaas wel voor dat hij nergens echt diep doordringt in de materie. Newman lijkt zicht te concentreren op het bieden van een overzicht. Hij komt met alle zaken die in het computerspel van belang zijn. Zo gaat hij bijvoorbeeld in op externe, zelfopgelegde 'spelregels' die kunnen ontstaan in de sociale context van de speelhal (pp. I8-22) en is hij de enige auteur die uitgebreid aandacht besteedt aan een kernbegrip als interactiviteit (bijvoorbeeld pp. 72-77). Op de onderwerpen die Newman behandelt is op zich weinig aan te merken. Zoals gezegd is Videogames vooral een goede introductie. Toch komt Newman niet tot duidelijke definities van het spel, spelaspecten of kernbegrippen, noch reikt hij ons een gedegen methode aan om spellen te analyseren. Laat staan dat hij duidelijk positie kiest in een aantal discussies die momenteel spelen. De enige momenten waarop Newman een eigen visie laat doorschemeren betreffen voornamelijk terzijdes, zoals de actieve rol van de secundaire (meekijkende) speler waarvoor hij zich sterk maakt. Hierdoor mist Videogames de focus die Trigger Happy boeiend maakt en mist het ook de academische scherpte van 
bijvoorbeeld Cybertext (Aarseth I997). Uiteindelijk biedt Videogames te weinig stof ter discussie en te weinig spanning om werkelijk een mijlpaal zijn.

Met wat meer scherpte kan ook een probleem voorkomen worden waarmee alle boeken over computerspellen te maken hebben: computerspellen ontwikkelen zich voorlopig nog razendsnel. Niet alleen in technisch opzicht maar ook in maatschappelijke functie en impact. Sinds 2000 hebben de zogenaamde Massive Multi-Player Online Role-Playing Games (M MOR PGs) de industrie danig veranderd. Waar Steven Poole zich nog verbaast over het feit dat in 2000 een U LTIMA O N LIN E spelkarakter voor enkele honderden dollars verkocht werd en het daarbij laat wat betreft M M R PGs, bestaan er nu bedrijven die geld verdienen door fictieve munten en goederen te verhandelen. Ik heb me zelfs eens laten vertellen dat de economie die gegenereerd wordt door het online spel EVERQUEST groter is dan de economie van Bulgarije. Hoewel ik het waarheidsgehalte van die uitspraak niet kan verifiëren, is het niet ongebruikelijk dat spelers vijfhonderd dollar uitgeven om hun spel van geld en uitrusting te voorzien. In EVERQUEST is de standaardprijs voor honderdduizend eenheden van de fictieve geldeenheid 'platinastukken' honderd dollar. Een goed ontwikkeld spelkarakter kan in het spel ongeveer vijfduizend platina stukken per uur verdienen door monsters te verslaan. Dat komt neer op vijf dollar per uur! Reden genoeg voor een fanatieke speler om op te merken dat hij: 'beter kan overwerken en de platina stukken online inkopen dan ze zelf te verdienen'.

Tegelijkertijd wachten spelers nog steeds op lang beloofde ontwikkelingen zoals pure virtual reality en ziet het er naar uit dat deze voorlopig nog niet gerealiseerd kunnen worden. Nieuwe genres kunnen hierdoor even snel opkomen als verdwijnen. Hoeveel 'platformspellen' worden er tegenwoordig nog op de PC uitgebracht? Dit maakt het moeilijk om trends te voorspellen en te analyseren. In dat opzicht moet de waarde van Newmans beschrijving van de opkomst van de 'retrogamers' die teruggaan naar oude klassieke spelen enigszins gerelativeerd worden. Vooralsnog betreft dit een kleine groep die waarschijnlijk weinig indruk maakt op de grote spellenindustrie. Hij had er beter aan gedaan om de klassieke spelelementen waarnaar de retrogamers terugverlangen te beschrijven en te bekijken en aan te geven welke kwaliteiten deze spellen hebben die tegenwoordig ontbreken. Maar een dergelijke analyse is in Videogames onmogelijk juist door het gebrek aan scherpte. En in dat opzicht is de discussie van Poole over het computerspel en realisme een stuk waardevoller.

\section{Noot}

I Een 'easter egg' is een verborgen plek of grap in een computerspel of programma. Om een 'easter egg' te vinden moeten vaak vreemde opdrachten of handelingen worden verricht. Mensen die 'easter eggs' vinden worden beloond met mooie plaatjes of andere aardigheden; zo is het mogelijk om in Word 97 te flipperen als de juiste handelingen worden uitgevoerd. Op internet zijn pagina's te vinden die vele 'easter eggs' beschrijven in tal van programma's en tegenwoordig zijn ze ook te vinden op DVD's. 